\title{
NOVEL COMPLEXES OF RUTHENIUM(III) WITH SCHIFF BASES AND INDAZOLE - SYNTHESIS AND CHARACTERIZATION
}

\author{
S. Begić ${ }^{*}$ N. Ljubijankić, S. Gojak-Salimović and E. Osmić \\ Department of Chemistry, Faculty of Science, University of Sarajevo, \\ 71000 Sarajevo, Bosnia and Herzegovina \\ *E-mail: baltazar.sabina@gmail.com
}

\begin{abstract}
Two novel cationic Ru(III) complex compounds with Schiff bases, $N$-phenyl-5-X-salicylideneimine (where $\mathrm{X}=\mathrm{H}$ or $\mathrm{Br}$ ) and indazole have been synthesized and characterized by various spectral and electrochemical analysis. The existence of molecular ions $\mathrm{M}^{+}$at $\mathrm{m} / \mathrm{z} 730.1652$ and 887.9818 corresponding to $\left[\mathrm{C}_{40} \mathrm{H}_{32} \mathrm{~N}_{6} \mathrm{O}_{2} \mathrm{Ru}\right]^{+}$and $\left[\mathrm{C}_{40} \mathrm{H}_{30} \mathrm{Br}_{2} \mathrm{~N}_{6} \mathrm{O}_{2} \mathrm{Ru}\right]^{+}$, respectively, was obtained by mass spectra analysis. The coordination of the ligands in the $\mathrm{Ru}(\mathrm{III})$ octahedral environment occurs through imine nitrogen, deprotonated phenolic oxygen atom from the Schiff bases as well as via the free electronic pair on the nitrogen atom in indazole. Furthermore, the effect of the cationic $\mathrm{Ru}(\mathrm{III})$ complexes on the Briggs-Rauscher oscillating reaction was preliminary studied and monitored potentiometrically.
\end{abstract}

Keywords: Ru(III) complex, Schiff base, indazole, Briggs-Rauscher, oscillation

(C) RASĀYAN. All rights reserved

\section{INTRODUCTION}

Schiff bases as a compound with azomethine linkage $(-\mathrm{C}=\mathrm{N}-)$ are versatile and very popular ligands for metal coordination ${ }^{1,2}$. Since Schiff bases show diverse biological activity, a significant number of metal complexes with various ligands have been synthesized and their activities against different targets have been investigated ${ }^{3-8}$. Antibacterial, antifungal, antiviral, antioxidant and cytotoxic activities have been reported $^{1,9-12}$. Ruthenium(III) complexes are of immense interest regarding their kinetic inertness ${ }^{13}$. Some ruthenium(III) complexes containing ON or ONS donor atoms were synthesized in our laboratory regarding interaction with DNA or genotoxic activity have been previously reported ${ }^{4,5,14} \cdot \mathrm{Ru}(\mathrm{III})$ complexes containing indazole, imidazolium trans-[tetrachlorobis(1H-indazole)ruthenate(III)] (KP1019) and sodium trans-[tetrachlorobis(1H-indazole)ruthenate(III)] (NKP-1339) have proofed an extraordinary antiproliferative properties and entered clinical trials ${ }^{15}$. The indazole ring system is a partial component of a huge number of biologically active compounds and most of them exhibit a broad spectrum of bioactivities ${ }^{16,17}$. Interaction of cationic complex $\mathrm{Ru}(\mathrm{III})$ containing indazole and Schiff base derived from 5-chlorosalicylaldehyde and aniline with DNA by spectrophotometric titration according to the calculated binding constant indicated non-covalent binding and was described as a major groove binding ${ }^{18}$. In this study, synthesis, characterization and the effect on the Briggs-Rauscher oscillating reaction of new $\mathrm{Ru}$ (III) cationic complexes with indazole and Schiff bases derived from salicylaldehyde or 5bromosalicyladehyde and aniline were reported. This is a continuation of the research activities of the synthesis and characterization of ruthenium(III) complexes with Schiff bases and $N$-heterocycles.

\section{Materials and Methods}

\section{EXPERIMENTAL}

All chemicals were of analytical grade, purchased from commercial suppliers. The matrix-assisted laser desorption/ionization (MALDI) mass spectrometer, 4800 Plus TOF/TOF (time-of-flight) (Applied

Rasayan J. Chem., 12(1), 294-299(2019)

http://dx.doi.org/10.31788/RJC.2019.1215112

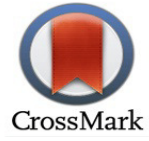


Biosystems Inc., Foster City, CA, USA) was used for obtaining the mass spectra. A small amount of complex was mixed with $10 \mu \mathrm{L}$ of 2,6-dihydroxyacetophenone $(5 \mathrm{mg} / \mathrm{mL})$ and $1 \mu \mathrm{L}$ was loaded on MALDI plate. Acquisitions were performed in negative ion reflection mode using thiamine mononitrate, azithromycin and angiotensin or positive mode with riboflavin and tripsin as internal standards. Mass spectra were obtained at mass range m/z 10 to $1000 \mathrm{Da}$ (focus mass $500 \mathrm{Da}$, delay time $300 \mathrm{~ns}$ ). Infrared spectra have been obtained at a BX FTIR Perkin Elmer Spectrum System in the range from 4000 to 400 $\mathrm{cm}^{-1}$ with samples prepared as potassium bromide $(\mathrm{KBr})$ pellets. Electronic spectra were recorded in $\mathrm{CH}_{2} \mathrm{Cl}_{2}$ using Perkin Elmer UV/Vis spectrometer model Lambda 35 in the $900-200 \mathrm{~nm}$ range. Cyclic voltammetry was performed by Autolab potentiostat/galvanostat PGSTAT 12 electrochemical analyzer equipped with three electrodes assembly. Glassy carbon (GC) was used as a working electrode, silver/silver chloride $(\mathrm{Ag} / \mathrm{AgCl})$ as a reference while platinum $(\mathrm{Pt})$ wire was an auxiliary electrode. The cyclic voltammograms were recorded in acetonitrile $(\mathrm{MeCN})$ at $0.2 \mathrm{Vs}^{-1}$ scan rate. Tetraethyl ammonium bromide $\left(\mathrm{Et}_{4} \mathrm{NBr}\right)$ was used as a supporting electrolyte. The Briggs Rauscher reaction mixture contained suitable volumes of an aqueous solution of hydrogen peroxide, potassium iodate, sulphuric acid, malonic acid, manganese(II) sulfate and starch. Oscillations in the Briggs-Rauscher reaction mixture were monitored potentiometrically by recording the potential changes of a $\mathrm{Pt}$ electrode versus $\mathrm{Ag} / \mathrm{AgCl}$ electrode at $25^{\circ} \mathrm{C}$.

\section{Synthesis of Cationic Compounds}

The preparation of diindazole-bis-[ $N$-phenyl-salicylideneiminato-O, $N)$ ruthenium(III) chloride, $[\mathrm{Ru}(N-\mathrm{Ph}-$ salim $\left.)_{2}(\text { ind })_{2}\right] \mathrm{Cl}$, hereafter Compound $\mathbf{1}$ and diindazole-bis-[ $N$-phenyl-5-bromosalicylideneiminato$\mathrm{O}, N)$ ruthenium(III) chloride, $\left[\mathrm{Ru}(N-\mathrm{Ph}-5-\mathrm{Br} \text {-salim })_{2}(\text { ind })_{2}\right] \mathrm{Cl}$, hereafter Compound 2 was carried out by heating under reflux an ethanol solution of sodium dichlorobis[ $N$-phenyl-5-X-salicylideneiminato$N, O$ ]ruthenate(III) $(0.1 \mathrm{mmol})$ where $\mathrm{X}=\mathrm{H}$, hereafter Starting compound $1(58.7 \mathrm{mg})$ or $\mathrm{Br}$, hereafter Starting compound $2(74.5 \mathrm{mg})$ with an ethanol solution of indazole $(0.2 \mathrm{mmol} ; 23.6 \mathrm{mg})$ (molar ratio of $\mathrm{Ru}(\mathrm{III})$ starting compound:indazole $=1: 2$ ). The mixtures were refluxed for seven hours at $75^{\circ} \mathrm{C}$ until the color changed from dark purple to blue-purple and from dark green to petroleum green for Compound 1 and 2, respectively. The final solution volumes were reduced by vacuum distillation to approximately 10 $\mathrm{mL}$ and kept in an ice-salt bath for one week. The precipitated complexes were filtered off and washed with water until the negative reaction on chloride ions. The products were vacuum dried in desiccators.

Compound-1: Yield: 53\%; MALDI TOF/TOF MS $(\mathrm{m} / \mathrm{z})$ calcd for $\left[\mathrm{C}_{40} \mathrm{H}_{32} \mathrm{~N}_{6} \mathrm{O}_{2} \mathrm{Ru}\right]^{+}, 730.1625$; found, 730.1652; IR $\left(\mathrm{KBr}, \mathrm{cm}^{-1}\right) 3434[\mathrm{v}(\mathrm{N}-\mathrm{H})], 1695[\mathrm{v}(\mathrm{C}=\mathrm{N})], 1356 \mathrm{~m}[\mathrm{v}(\mathrm{C}-\mathrm{N})], 1082[\mathrm{v}(\mathrm{N}-\mathrm{N})], 664 \mathrm{w}$ $\left[v(\mathrm{Ru}-\mathrm{N}), 423 \mathrm{w}[\mathrm{v}(\mathrm{Ru}-\mathrm{O})]\right.$; UV-Vis $\left(\mathrm{CH}_{2} \mathrm{Cl}_{2}, \lambda / \mathrm{nm}\right) 235,283,578$.

Compound-2: Yield: 61\%; MALDI TOF/TOF MS (m/z) calcd for $\left[\mathrm{C}_{40} \mathrm{H}_{30} \mathrm{Br}_{2} \mathrm{~N}_{6} \mathrm{O}_{2} \mathrm{Ru}\right]^{+}$, 887.9828; found, 887.9818; IR $\left(\mathrm{KBr}, \mathrm{cm}^{-1}\right) 3435[\mathrm{v}(\mathrm{N}-\mathrm{H})], 1706[\mathrm{v}(\mathrm{C}=\mathrm{N})], 1356 \mathrm{~m}[\mathrm{v}(\mathrm{C}-\mathrm{N})], 1081[\mathrm{v}(\mathrm{N}-\mathrm{N})], 662 \mathrm{w}$ $\left[v(\mathrm{Ru}-\mathrm{N}), 414 \mathrm{w}[\mathrm{v}(\mathrm{Ru}-\mathrm{O})]\right.$; UV-Vis $\left(\mathrm{CH}_{2} \mathrm{Cl}_{2}, \lambda / \mathrm{nm}\right) 245,282,350,574$.

\section{Synthesis}

RESULTS AND DISCUSSION

The starting compounds 1 and 2 were prepared according to the published procedures that involved adding ethanol solution of suitable Schiff base, $N$-phenyl-5-X-salicylideneimine where $\mathrm{X}=\mathrm{H}$ or $\mathrm{Br}(2$ $\mathrm{mmol})$ to an ethanol solution of ruthenium(III) chloride $(1 \mathrm{mmol})$ followed by heating under reflux for 3 hours at $65^{\circ} \mathrm{C}$. Addition of one millilitre of $2 \mathrm{mmol}(0.117 \mathrm{~g}) \mathrm{NaCl}$ was made in order to precipitate the starting compounds ${ }^{14,19}$.

Novel cationic $\mathrm{Ru}(\mathrm{III})$ complexes, $\left[\mathrm{Ru}(\mathrm{N} \text {-Ph-5-X-salim })_{2}(\mathrm{ind})_{2}\right] \mathrm{Cl}$, where $\mathrm{X}=\mathrm{H}$ or $\mathrm{Br}$ and ind $=$ indazole, have been synthesized from ethanol solutions of starting compounds $(0.1 \mathrm{mmol})$ and indazole $(0.2 \mathrm{mmol})$ in molar ratio 1:2 as shown in Fig.-1. In relative moderate reaction conditions indazole replaced two easily outgoing chloride ions in the starting compounds. New cationic $\mathrm{Ru}(\mathrm{III})$ complexes were indigo blue 
RASĀYAN J. Chem.

Vol. 12 | No. 1 |294 - 299| January - March | 2019

(Compound 1) and green (Compound 2), air and light resistant, soluble in acetonitrile (MeCN), dimethylformamide (DMF), dimethyl sulphoxide (DMSO) and chloroform.

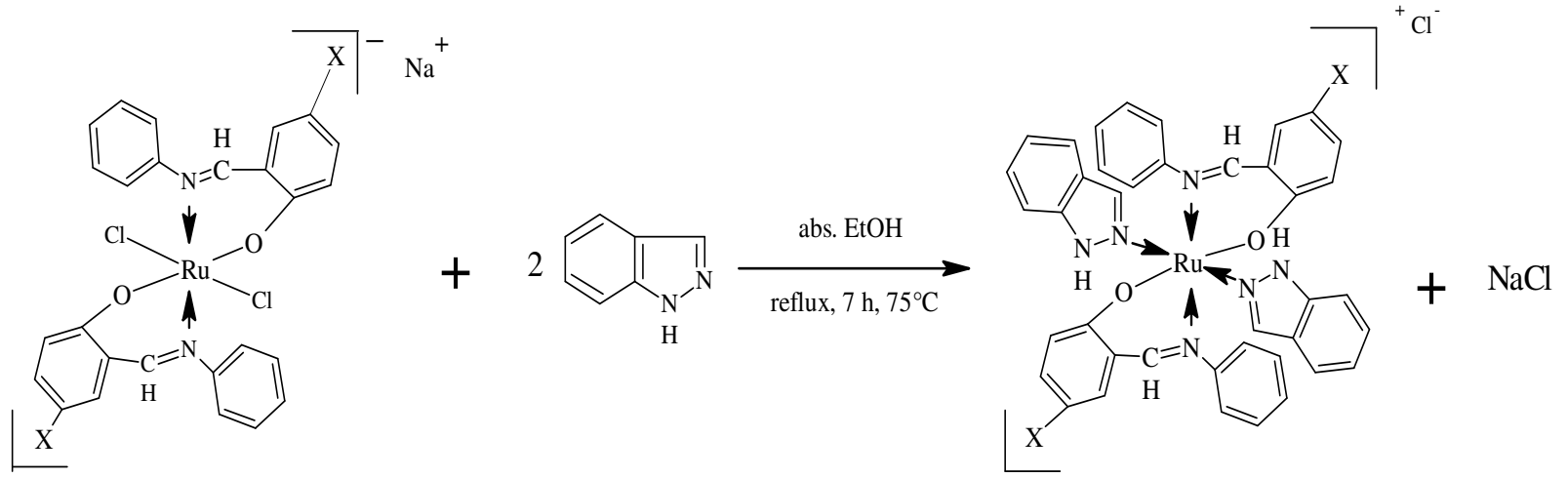

Fig.-1: The Synthesis of $\left[\mathrm{Ru}(\mathrm{N}-\mathrm{Ph}-5-\mathrm{X}-\mathrm{salim})_{2}(\mathrm{ind})_{2}\right] \mathrm{Cl}$ where $\mathrm{X}=\mathrm{H}$ or $\mathrm{Br}$

\section{Spectral Characterization}

The characterization of $\mathrm{Ru}(\mathrm{III})$ compounds before and after synthesis with indazole was obtained by MALDI TOF/TOF mass spectrometry (Table-1) and infrared spectroscopy (Table-2). Obtained results confirmed the presence of anionic compounds in starting complexes, as well as cationic compounds in synthesized complexes.

Important proofs regarding functional groups coordinated to ruthenium(III) were obtained. Based on the comparison of infrared spectra of starting complexes, free indazole and synthesized compounds, the coordination of anionic bidentate Schiff bases and monodentate indazole to the ruthenium(III) ion was confirmed.

Table-1: MALDI TOF/TOF Results of the starting and Synthesized Complexes

\begin{tabular}{c|l|c|c|c}
\hline Compound & \multicolumn{1}{|c|}{ Molecular ion } & $\begin{array}{c}\text { Calc. mass } \\
\mathrm{m} / \mathrm{z}(100 \%)\end{array}$ & $\begin{array}{c}\text { Measured Mass } \\
\mathrm{m} / \mathrm{z}(100 \%)\end{array}$ & $\begin{array}{c}\text { Mass Error } \\
/ \mathrm{ppm}\end{array}$ \\
\hline Starting compound 1 & {$\left[\mathrm{C}_{26} \mathrm{H}_{20} \mathrm{Cl}_{2} \mathrm{~N}_{2} \mathrm{O}_{2} \mathrm{Ru}\right]^{-}$} & 563.9952 & 563.9949 & 0.53 \\
\hline Starting compound 2 & {$\left[\mathrm{C}_{26} \mathrm{H}_{18} \mathrm{Br}_{2} \mathrm{Cl}_{2} \mathrm{~N}_{2} \mathrm{O}_{2} \mathrm{Ru}\right]^{-}$} & 721.8143 & 721.8130 & 1.80 \\
\hline Compound 1 & {$\left[\mathrm{C}_{40} \mathrm{H}_{32} \mathrm{~N}_{6} \mathrm{O}_{2} \mathrm{Ru}\right]^{+}$} & 730.1625 & 730.1652 & 1.37 \\
\hline Compound 2 & {$\left[\mathrm{C}_{40} \mathrm{H}_{30} \mathrm{Br}_{2} \mathrm{~N}_{6} \mathrm{O}_{2} \mathrm{Ru}\right]^{+}$} & 887.9828 & 887.9818 & 1.13 \\
\hline
\end{tabular}

The main IR vibrations are given in Table-2. Indazole was coordinated to $\mathrm{Ru}(\mathrm{III})$ via a free electronic pair of nitrogen affecting the $\mathrm{C}=\mathrm{N}, \mathrm{C}-\mathrm{N}, \mathrm{N}-\mathrm{N}$ and $\mathrm{N}-\mathrm{H}$ stretching vibrations. In Compound 1 and Compound $2, \mathrm{C}=\mathrm{N}$ stretching vibrations were shifted for 6 and $5 \mathrm{~cm}^{-1}$ toward higher wave numbers, while N-N stretching vibrations were shifted for 6 and $9 \mathrm{~cm}^{-1}$, respectively ${ }^{20}$. The symmetric stretching vibration of the C-N linkage was obtained at $1356 \mathrm{~cm}^{-1}$ in the spectra of free indazole. In the synthesized complexes, a new medium intensity band at $1356 \mathrm{~cm}^{-1}$ was observed. Since C-N bond is conjugated to the benzene ring, significant shifts after coordination of indazole to $\mathrm{Ru}$ (III) were not expected because there is no change in the bond length. In the spectra of uncoordinated indazole, $\mathrm{N}-\mathrm{H}$ stretching vibration appeared at $3410 \mathrm{~cm}^{-1}$. This vibration is coupled with vibration in the starting compounds and appears at $3434 \mathrm{~cm}^{-1}$ in both synthesized complexes. The weak bands at $664(662) \mathrm{cm}^{-1}$ and 423 (414) $\mathrm{cm}^{-1}$ in Compound 1 (Compound 2) could be assigned to $\mathrm{Ru}-\mathrm{N}$ and $\mathrm{Ru}-\mathrm{O}$, respectively.

In starting compounds, $\mathrm{Na}\left[\mathrm{RuCl}_{2}(\mathrm{~N} \text {-Ph-5-X-salim })_{2}\right]$ where $\mathrm{X}=\mathrm{H}$ or $\mathrm{Br}$, characteristic IR vibrations were $\mathrm{C}=\mathrm{N}$ (azomethine), $\mathrm{C}-\mathrm{O}$ (phenolic), $\mathrm{Ru}-\mathrm{N}$ and $\mathrm{Ru}-\mathrm{O}$. After the coordination of indazole to $\mathrm{Ru}(\mathrm{III})$ these vibrations were not affected. Regarding infrared spectra, as anionic bidentate ligands nitrogen from azomethine group and oxygen from deprotonated phenol group were coordinated to the octahedral environment of ruthenium(III) in Schiff bases, while indazole was coordinated via nitrogen atom as a monodentate ligand.

UV/Vis spectra exhibited a few characteristic absorptions given in Table-3. The free indazoles showed two absorption bands attributed to the transitions from $\pi$ to $\pi^{*}$ and $n$ to $\pi^{*}$ relating benzene ring. Shifting 
RASĀYAN J. Chem.

Vol. 12 | No. 1 |294 - 299| January - March | 2019

of $n \rightarrow \pi^{*}$ band in synthesized compounds spectra followed the participation of nitrogen from indazole in bonding. The weak broad absorption bands of $\mathrm{Na}\left[\mathrm{RuCl}_{2}(\mathrm{~N}-\mathrm{Ph}-5-\mathrm{X} \text {-salim })_{2}\right]$ centered at $613 \mathrm{~nm}$ for $\mathrm{X}=\mathrm{H}$ or $625 \mathrm{~nm}$ for $\mathrm{X}=\mathrm{Br}$ have been assigned to ${ }^{2} \mathrm{~T}_{2 \mathrm{~g}} \rightarrow{ }^{2} \mathrm{~A}_{2 \mathrm{~g}}$ transition ${ }^{14}$.

Table-2: Characteristic IR Vibrations $\left(\mathrm{cm}^{-1}\right)$ of starting Compounds, Synthesized Complexes and Free

\begin{tabular}{l|c|c|c|c|c}
\multicolumn{7}{l}{ Indazole } \\
\hline & 1 & 2 & Compound 1 & Compound 2 & Ind \\
\hline$v(\mathrm{~N}-\mathrm{H})_{\text {Ind }}$ & - & - & 3434 & 3434 & 3410 \\
\hline$v(\mathrm{C}=\mathrm{C})_{\text {Ind }}$ & - & - & 1626 & 1624 & 1621 \\
\hline$v(\mathrm{C}=\mathrm{N})_{\mathrm{SB}}$ & 1605 & 1600 & 1605 & 1600 & - \\
\hline$v(\mathrm{C}=\mathrm{N})_{\text {Ind }}$ & - & - & 1695 & 1698 & 1689 \\
\hline$v(\mathrm{C}-\mathrm{N})_{\text {Ind }}$ & - & - & 1356 & 1356 & 1356 \\
\hline$v(\mathrm{C}=\mathrm{O} \text { Ph })_{\mathrm{SB}}$ & 1295 & 1289 & 1295 & 1289 & - \\
\hline$v(\mathrm{~N}-\mathrm{N})_{\text {Ind }}$ & - & - & 1082 & 1081 & 1076 \\
\hline$v(\mathrm{Ru}-\mathrm{N})$ & 664 & 662 & 664 & 662 & - \\
\hline$v(\mathrm{Ru}-\mathrm{O})$ & 423 & 414 & 423 & 414 & - \\
\hline
\end{tabular}

This transitions shifted towards higher energies in the spectra of complexes with indazole (578 $\mathrm{nm}$ for $\mathrm{X}$ $=\mathrm{H}$ and $574 \mathrm{~nm}$ for $\mathrm{X}=\mathrm{Br}$ ). The substitution of two chloride ions in the starting complexes with indazole resulted in higher separation energies of d-atomic orbitals. The chloride ion is a weaker ligand than indazole in accordance with the spectrochemical series. Indazole splits stronger crystal filed and shifts d-d transition to lower wavelengths.

Table-3: The Characteristic Absorptions (nm) in Electronic Spectra of Starting Compounds, Synthesized Complexes and Free Indazole in $\mathrm{CH}_{2} \mathrm{Cl}_{2}$

\begin{tabular}{l|c|c|c|c|c}
\hline & $\begin{array}{c}\text { Starting } \\
\text { compound 1 }\end{array}$ & $\begin{array}{c}\text { Starting } \\
\text { compound 2 }\end{array}$ & Compound 1 & Compound 2 & Ind \\
\hline$\pi \rightarrow \pi^{*}$ & 239 & 244 & 235 & 245 & 250 \\
\hline $\mathrm{n} \rightarrow \pi^{*}$ & $\mathrm{sh}$ & $\mathrm{sh}$ & 283 & 282 & 285 \\
\hline $\mathrm{IL}(\mathrm{SB})$ & 348 & 351 & $\mathrm{sh}$ & 350 & - \\
\hline $\mathrm{d}-\mathrm{d}$ & 613 & 625 & 578 & 574 & - \\
\hline
\end{tabular}

$\pi \rightarrow \pi *$ - electronic transition of delocalized electrons of the aromatic system; $n \rightarrow \pi *$ - electronic transitions of the atoms of azomethine group or free electron pair on the $\mathrm{N}$ atom of indazole with aromatic $\pi$ electrons; IL (SB) - intraligand transition of whole Schiff base molecule; d-d transition of low spin complex; sh-shoulder.

Compounds 1 and 2 were insoluble in water and therefore the cyclic voltammograms were recorded in acetonitrile solution with the use of glassy carbon working electrode (GCE). In this study, tetraethyl ammonium bromide $\left(\mathrm{Et}_{4} \mathrm{NBr}\right)$ was used as a supporting electrolyte. Cyclic voltammetry data are given in Table-4. Cyclic voltammograms of the Compounds 1 and 2 showed well-defined anode and cathode peaks. The values of formal potentials ( $\left.\mathrm{E}_{1 / 2}\right)$ assigned to $\mathrm{Ru}(\mathrm{III}) / \mathrm{Ru}$ (II) couple indicated that $\mathrm{Ru}$ (III) in the complexes was stabilized via $\mathrm{ON}_{2}$ ligands. Quasi-reversible one-electron transfer process was indicated by $i_{k} / i_{a}$ ratio and the peak to peak separation $\left(\Delta \mathrm{E}_{\mathrm{p}}\right)$ in cyclic voltammograms ${ }^{22}$.

Table-4: The Cyclic Voltammetric Data of Compounds 1 and 2 in Acetonitrile Solutions

\begin{tabular}{l|l|l|l|c}
\hline & $\mathrm{E}_{\mathrm{pc}} / \mathrm{V}$ & $\mathrm{E}_{\mathrm{pa}} / \mathrm{V}$ & $\mathrm{E}_{1 / 2} / \mathrm{V}$ & $\Delta \mathrm{E}_{\mathrm{p}} / \mathrm{mV}$ \\
\hline Compound 1 & -0.918 & -0.720 & -0.819 & 198 \\
\hline Compound 2 & -0.924 & -0.723 & -0.824 & 201 \\
\hline
\end{tabular}

Supporting electrolyte: $\mathrm{Et}_{4} \mathrm{NBr}$; potential range: $(-1.1)-(-0.5) \mathrm{V}$; scan rate: $0.2 \mathrm{~V} / \mathrm{s}$; all data are referred to $\mathrm{Ag} / \mathrm{AgCl}$ reference electrode; $\mathrm{E}_{1 / 2}=0.5\left(\mathrm{E}_{\mathrm{pa}}+\mathrm{E}_{\mathrm{pk}}\right)$ where $\mathrm{E}_{\mathrm{pa}}-$ anodic potential, $\mathrm{E}_{\mathrm{pk}}-$ cathodic potential. 
RASĀYAN J. Chem.

Vol. 12 | No. 1 |294 - 299| January - March | 2019

\section{The Effect on the Briggs-Rauscher Oscillating Reaction}

The $\mathrm{pH}$ value of the Briggs-Rauscher reaction mixture was around 2. This value in part mimics the physiological conditions similar to the fluids in the human stomach ${ }^{23,24}$. Synthesized Ru(III) complexes were dissolved in absolute ethanol after initial dissolving in DMSO and after third oscillation, an appropriate volume was added to the reaction mixture. An immediate effect on quenching of oscillations was caused by an addition of the compound solution. The elapsed time between ending the addition and first regenerated oscillation was defined as inhibition time $\left(t_{\text {inhib }}\right)$. After $t_{\text {inhib }}$ the oscillations were restarted with different amplitude and frequency compared to a non-inhibited Briggs-Rauscher reaction mixture ${ }^{23}$. Plotting $t_{\text {inhib }}$ vs. concentration of the compounds, linear correlations were found in the range of 5.36 to $21.0 \mu \mathrm{mol} / \mathrm{L}$ (Fig.-2) and obtained parameters are listed in Table-5.

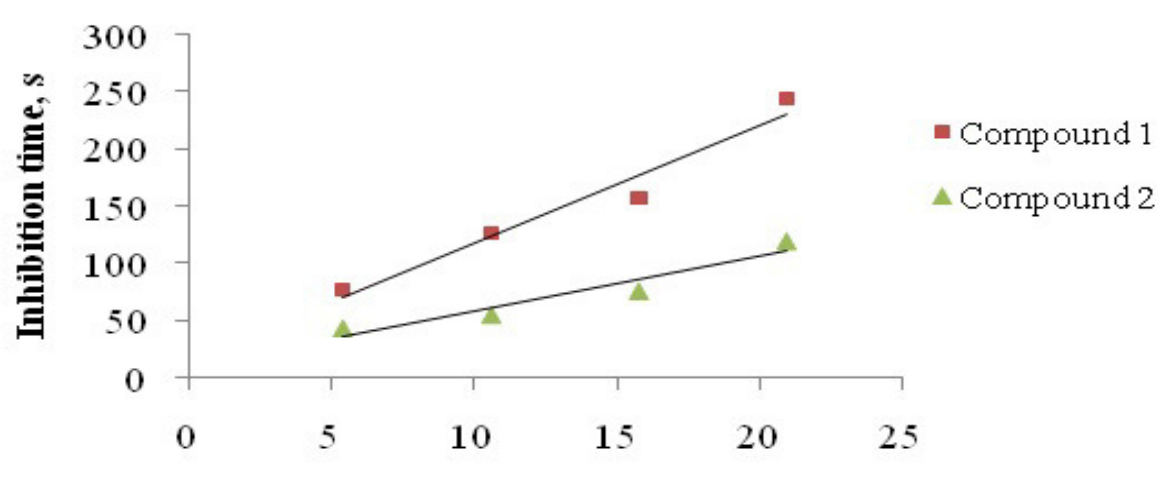

Concentration, $\mu \mathrm{mmol} / \mathrm{L}$

Fig.-2: Inhibition time versus compounds concentration

The path of the immediate quenching of oscillations - inhibition time - resumption of oscillations was similar to antioxidant free radical scavenger ${ }^{24}$. However, the obtained preliminary results suggested further examination of this effect.

Table-5: Parameters of the Straight Line Equations $t_{\text {inhib }}=m$ [compound $]+q$

\begin{tabular}{l|c|c|c}
\hline Complex & $m(\mathrm{~s} \mathrm{~L} / \mu \mathrm{mol})$ & $q(\mathrm{~s})$ & $R^{2}$ \\
\hline Compound 1 & 10.3 & 15.8 & 0.955 \\
\hline Compound 2 & 4.82 & 9.80 & 0.958 \\
\hline
\end{tabular}

\section{CONCLUSION}

Two new cationic complex compounds of Ru(III) with Schiff bases, $N$-phenyl-5-X-salicylideneimine (where $\mathrm{X}=\mathrm{H}$ or $\mathrm{Br}$ ) and indazole were synthesized. Based on the experimental results, the complexes were formulated as $\left[\mathrm{Ru}(\mathrm{N} \text {-Ph-5-X-salim })_{2}(\mathrm{ind})_{2}\right] \mathrm{Cl}$ where $\mathrm{X}=\mathrm{H}$ or $\mathrm{Br}$, ind $=$ indazole. In the obtained $\mathrm{Ru}$ (III) octahedral complexes, Schiff bases acted as an anionic bidentate $\mathrm{O}, \mathrm{N}$ donor ligands, while indazole occurred as a monodentate $\mathrm{N}$ ligand. The perturbation path was similar to that stimulated by an antioxidant free radical scavenger.

\section{REFERENCES}

1. A. Hameed, M. al-Rashida, M. Uroos, S.A. Ali and K.M. Khan, Expert Opinion on Therapeutic Patents, 27(1), 63(2017), DOI: 10.1080/13543776.2017.1252752.

2. S.R. Khapate, S.H. Garandal, A.A. Auti, M.V. Yadav, F.G. Khan and D. S. Wankhede, Rasayan J. Chem, 11(4), 1461(2018), DOI: 10.31788/RJC.2018.1144048

3. N. P. Priya, S. Arunachalam, A. Manimaran, D. Muthupriya and C. Jayabalakrishnan, Spectrochimica Acta Part A: Molecular and Biomolecular Spectroscopy, 72, 670(2009), DOI:10.1016/j.saa.2008.10.028. 
RASĀYAN J. Chem.

Vol. 12 | No. 1 |294 - 299| January - March | 2019

4. N. Ljubijankić, S. Begić, A. Ljubović-Dedeić, M. Stanković, I. Salimović-Bašić, M. Jadranin, B. Bencun and S. Ljubijankić, Rasayan J. Chem, 11(4), 1511(2018), DOI:10.31788/RJC.2018.1145021

5. N. Ljubijankić, M. Stanković, V. Tešević, S. Grgurić-Šipka, M. Jadranin, S. Begić, and E. Šabanović, Rasayan J. Chem, 11(2), 647(2018), DOI: 10.7324/RJC.2018.1123004

6. N.K. Kar, M.K. Singh and R.A. Lal, Arabian Journal of Chemistry, 10(1), S76(2017), DOI:10.1016/j.arabjc.2012.05.007

7. A. Cipurković, E. Horozić, N. Ljubijankić, A. Odobašić, S. Galijašević and M. Saletović, Rasayan J. Chem., 10(4), 1381(2017), DOI:_10.7324/RJC.2017.104190

8. D. Gambino, Curr. Med. Chem., 17(31), 3616(2010), DOI: 10.2174/092986710793213797

9. H.K. Thompson and C. Orvig, Dalton T., 761 (2006), DOI: 10.1039/b513476e

10. N. Dharmaraj, P. Viswanathamurthi and K. Natarajan, Transition Metal Chemistry 26, 105(2001), DOI:10.1023/A:1007132408648

11. N. Thilagavathi, A. Manimaran and C. Jayabalakrishnan, Journal of Coordination Chemistry, 63(7), 1252(2010), DOI: 10.1080/00958971003735440

12. I.P. Ejidikea and P.A. Ajibadea, Journal of Coordination Chemistry, 68(14), 2552(2015), DOI: 10.1080/00958972.2015.1043127

13. S.H. van Rijit and P.J. Sadler, Drug Discov. Today, 14(23-24), 1089(2009), DOI:10.1016/j.drudis.2009.09.003

14. N. Ljubijankić, A. Zahirović, E. Turkušić and E. Kahrović, Croatica Chemica Acta, 86(2), 215 (2013), DOI: $10.5562 / \mathrm{cca} 2216$

15. A. Bijelic, S. Theiner, B.K. Keppler and A. Rompel, J. Med. Chem., 59, 5894 (2016), DOI: 10.1021/acs.jmedchem.6b00600

16. D.D. Gaikwad, A.D. Chapolikar, C.G. Devkate, K.D. Warad, A.P. Tayade, R.P. Pawar and A.J. Domb, European Journal of Medicinal Chemistry, 90, 707 (2015), DOI: 10.1016/j.ejmech.2014.11.029

17. G.E. Büchel, I.N. Stepanenko, M. Hejl, M.A. Jakupec, B.K. Keppler, P. Heffeter, W. Berger, and V.B. Arion, Journal of Inorganic Biochemistry, 113, 47 (2012), DOI: 10.1016/j.jinorgbio.2012.04.001

18. A. Zahirović, S. Begić-Hairlahović, N. Ljubijankić, E. Turkušić and E. Kahrović, In Abstracts of International Turkish Congress on Molecular Spectroscopy, Istanbul, Turkey, p. 88 (2013).

19. E. Kahrović, 2014, Ruthenium compounds with Schiff bases: design and promising applications of salicylideimine complexes, in: G.P. Keeler (Ed.), Ruthenium: Synthesis, Physicochemical Properties and Applications, Nova Science Publishers, Inc., New York, pp: 269-283.

20. J. Oomens, G. Meijer, G. von Helden, International Journal of Mass Spectrometry, 249-250, 199 (2006), DOI: 10.1016/j.ijms.2005.12.034

21. S. Begić-Hairlahović, E. Kahrović and E. Turkušić, In Abstracts of Congress of Chemists and Chemical Engineers of Bosnia and Herzegovina with International Participation, Sarajevo, Bosnia and Herzegovina, p. 88 (2014).

22. P. Zanello, Inorganic Electrochemistry-Theory, Practice and Application, The Royal Society of Chemistry, pp. 64-66 (2003).

23. I.P. Ejidike and P.A. Ajibade, Bioinorganic Chemistry and Applications, 2016, Article ID 9672451, DOI: $10.1155 / 2016 / 9672451$.

24. R. Cervellati and S.D. Furrow, Russian Journal of Physical Chemistry A, 87(13), 2121 (2013), DOI: 10.1134/S0036024413130086

[RJC-5112/2017] 